\title{
Natural history of coarctation of the aorta
}

\author{
Maurice Campbell \\ From the Cardiac Department, Guy's Hospital, London S.E.I, and the Institute of Cardiology, \\ London W.I
}

With the increasing number of subjects with coarctation of the aorta having operations, its natural history becomes more difficult to determine. The expectation of life has been calculated by two quite independent methods: (I) from 304 reported necropsies, and (2) from 22 deaths among I6I subjects followed for 716 patient-years. These were mostly patients rather than unselected schoolchildren, but many were quite free from symptoms and were sent only because a murmur was heard on examination.

Knowing how long they had been under observation, mortality rates could be calculated for each decade. They rise gradually but not very regularly, from $I \cdot 6$ per cent in the first two decades to 6.7 per cent per annum in the sixth and later decades.

The two methods give results in close agreement, closer than could be expected considering the relatively small numbers of patients and patient-years. The percentages of deaths at the end of each decade found by the two methods never differ by more than \pm 4 per cent and are often much closer. Of those surviving the serious hazards of the first one or two years, 25 per cent die before they reach 20, 50 per cent by 32, 75 per cent by 46, and 90 per cent by 58 years.

The arithmetical mean of the ages of death is 34 years instead of 7 I years as normally. These means, however, hide a very wide range, with standard deviations of at least \pm 15 per cent. For coarctation the median is $3 I$ years and the mode is widely spread through the second to fifth decades rather than closely clustered round a point.

This poor outlook makes an operative mortality in the region of 5 per cent a small price to pay for the greatly increased security afterwards. We do not yet know how much the risk of bacterial endocarditis or of intracranial haemorrhage will be reduced in the long run because there may be bicuspid aortic valves or intracranial berry aneurysms.

The exact incidence of subacute bacterial endocarditis is uncertain, somewhere between 0.6 (from necropsy series) and $I \cdot 3$ per cent per annum in clinical series. The range was similar for persistent ductus arteriosus, but paradoxically $I .5$ for the necropsy series and 0.5 for the clinical series. Clearly the incidence is high in all the four malformations shown in Table 5, about 0.9 \pm 0.4 per cent per annum.

The difficulties in determining the natural history of most cardiac malformations were described in a paper on the natural history of persistent ductus arteriosus (Campbell, 1968a). In that paper I was able to study the progress of about 240 personal and reported patients followed for 2,58I patient-years, the sum of the number of years each patient had been under observation before death or operation or being lost sight of. With congenital aortic stenosis (Campbell, I968b), I was able to study the outlook for 385 children followed for 2,5IO patient-years, though for adults I was dependent on my own 87 patients followed for 782 patient-years. With numbers as

Received 8 January 1970. large as these, it seemed the method most likely to give a reasonably accurate picture of their natural history.

With coarctation of the aorta, however, I have found only 161 patients followed for 716 patient-years, so results from this must be less reliable. I shall, therefore, consider first conclusions from 304 reported deaths of subjects with coarctation: here the available evidence is larger and perhaps more representative than the similar evidence for congenital aortic stenosis or for persistent ductus.

\section{Reported necropsies of coarctation}

Abbott (1928) collected 200 reported necropsies of subjects over the age of 2 years with coarctation of the aorta, all that she could find. 
TABLE I Age at death in 304 reported necropsies

\begin{tabular}{|c|c|c|c|c|c|c|c|c|c|}
\hline \multirow[t]{2}{*}{ Author } & \multirow{2}{*}{$\begin{array}{c}\text { No. of } \\
\text { cases }\end{array}$} & \multicolumn{8}{|c|}{ Percentages in each decade } \\
\hline & & $2-9$ & $10-19$ & $20-29$ & $30-39$ & $40-49$ & $50-59$ & $60-69$ & $\begin{array}{l}70 \text { and } \\
\text { over }\end{array}$ \\
\hline $\begin{array}{l}\text { Abbott (1928) } \\
\text { Reifenstein et al. (1947) } \\
\text { Total }\end{array}$ & $\begin{array}{l}200 \\
104 \\
304\end{array}$ & $\begin{array}{l}4 \cdot 5 \\
5 \\
4 \cdot 7\end{array}$ & $\begin{array}{l}22 \cdot 5 \\
17 \cdot 5 \\
20 \cdot 7\end{array}$ & $\begin{array}{l}24 \cdot 5 \\
22 \\
23 \cdot 6\end{array}$ & $\begin{array}{l}22 \cdot 5 \\
15 \cdot 5 \\
20 \cdot 2\end{array}$ & $\begin{array}{l}14 \\
25 \\
17 \cdot 6\end{array}$ & $\begin{array}{l}6 \\
7 \\
6 \cdot 3\end{array}$ & $\begin{array}{l}5 \\
7 \\
5 \cdot 6\end{array}$ & $\begin{array}{l}1 \\
2 \\
1 \cdot 3\end{array}$ \\
\hline $\begin{array}{l}\text { Per cent dead at end of } \\
\text { each decade }\end{array}$ & & $4 \cdot 7$ & 25.4 & 49 & $69 \cdot 2$ & $86 \cdot 8$ & $93 \cdot I$ & $98 \cdot 7$ & 100 \\
\hline
\end{tabular}

It was one of her great papers. Reifenstein, Levine, and Gross (1947) added an excellent account of 104 others that had been reported since. The ages of death in these two papers (Table I) agree well except that the second had more deaths in the fifth and fewer in the fourth decade than the first paper. This may be by chance or possibly from less heavy exertion in the working lives of many people.

These two papers include 304 deaths of subjects with coarctation, practically all that had been reported up to the time when the introduction of operations made a study of its natural history much more difficult. They contain a mass of information about coarctation of the aorta which was probably better documented than any other congenital cardiac malformation at that time.

There was no similar information about congenital aortic stenosis. Abbott (1936) gave the mean age of death of her 23 patients as only 13.9 years, probably because in most patients who lived longer the stenosis was not recognized as congenital and was regarded as rheumatic or later as calcific aortic stenosis. For persistent ductus, the best sources were two papers with 80 and 60 reported necropsies, a total of less than 140 because there was some overlapping (Bullock, Jones, and Dolley, 1939; Shapiro and Keys, 1943). Further, many thought that they included an undue proportion of younger patients, and that persistent ductus was often missed in older patients by pathologists at necropsy as well as by clinicians.

Admittedly physicians were hardly aware of coarctation as a condition to be diagnosed in life, and must have recognized it only in a very small proportion of their patients. For example, John Fawcett (1905) reported 18 necropsies he had performed on patients with coarctation, an excellent paper included by Abbott (1928). I was his student and later his medical registrar for four years in the 1920's so spent many hours listening to his teaching. I never heard him refer to coarctation, and it was years later when I found his paper. Clearly he thought this a subject one studied at necropsy and not in life, and this was characteristic of the period.

Lewis (1933) described how many of his army pensioners were under his observation for several years with high blood pressure before he recognized that they had coarctation, and it was he who taught many of us the easy method of diagnosis by feeling the femoral pulse.

TABLE 2 Causes of death in coarctation of the aorta (304 necropsies)

\begin{tabular}{llll}
\hline Causes of death & Per cent & \multicolumn{2}{l}{$\begin{array}{l}\text { Mean age and usual } \\
\text { decades }\end{array}$} \\
\hline Congestive heart failure & & 39 & 3rd to 5th \\
Not directly connected & $25 \cdot 5$ & 47 & 4th to 6th \\
Aortic rupture & 24 & 25 & 2nd and 3rd \\
Bacterial endocarditis & $2 \mathrm{I}$ & 29 & First five \\
Intracranial haemorrhage & I8 & 29 & 2nd and 3rd \\
\hline All cases & II.5 & 34.4 years \\
\hline
\end{tabular}

In contrast to the physicians, pathologists had been very interested for a long time and probably rarely missed coarctation at necropsies. The usual causes of death in 304 subjects are shown in Table 2. The fact that in nearly one-quarter the cause of death was not directly related to the coarctation shows that they often found it when there had been no reason to suspect it clinically.

There is no proof that patients who have necropsies in hospital and are subsequently reported are representative of the general population with coarctation. Patients dying in hospital with bacterial endocarditis may be overrepresented, and those dying later in life with congestive heart failure may be underrepresented, but equally may be specially likely to be reported if they have reached a good age. With the varied modes of death 


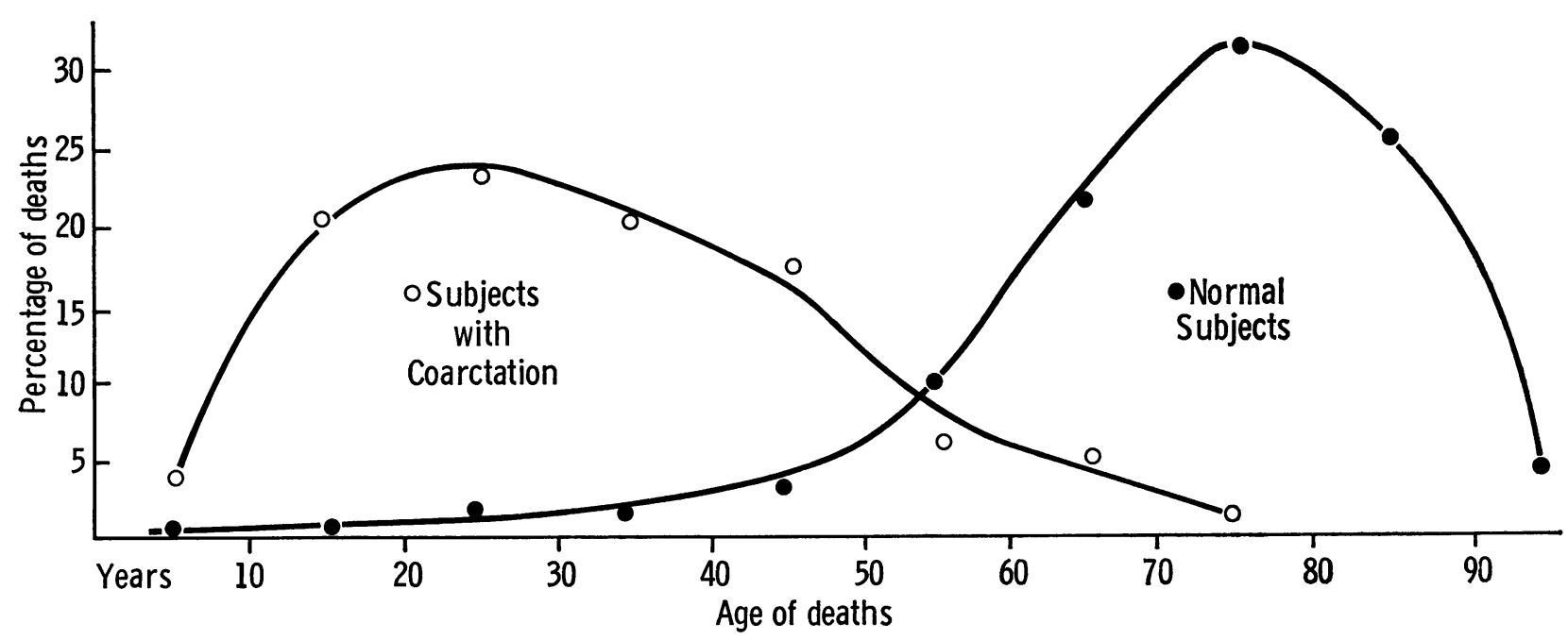

FIG. I The distribution of deaths by age, excluding deaths in the first year of life. In coarctation on the left and in normal subjects on the right, there is relatively little overlapping. For coarctation, the more rounded curve from reported necropsies is shown but the flatter curve from my calculations from deaths of patients under observation is similar (see Fig. 2).

and the interest shown by many pathologists, it seems reasonable to think that the 304 patients shown in the bottom line of Table $\mathbf{I}$ are representative of the general population with coarctation; and give a fairly correct picture of the natural mortality. In any case it was until now the only source of information available.

\section{Ages at death in reported necropsies}

These are shown in Fig. I and in the bottom line of Table $\mathrm{I}$. Of all subjects who survive the first two years of life, 25 per cent die befor $e$ they reach 20 , over 50 per cent by 30 or 31 , 75 per cent by 43 , and 90 per cent before 55 years.

Fig. I contrasts the age distribution of deaths of subjects with coarctation with those of the general population. Both curves are more skew-sided than normal frequency curves. Among the normal population nearly 90 per cent of the deaths occur after 50 years of age: there is a peak near 75 years and a low extension covering the first four or five decades. Among those with coarctation, nearly 90 per cent of the deaths occur before 50 years, 82 per cent between Io and 49, and fairly equally distributed between these four decades. I shall now proceed with other quite independent evidence about the mortality and expectation of life which, in fact, proves to be in reasonable agreement with these figures.

The position in 1956 I became interested in coarctation in 1933 when by chance I had two boys with the condition in adjacent beds. Even so, I saw only 15 patients in the next 14 years and 5 of them were in 1946 (Campbell and Suzman, 1947). When Campbell and Baylis (1956) wrote on the subject the numbers had increased to 130 patients, of whom I 12 were in the first three decades and rather more than one-third were girls or women. This was mainly 'an attempt to assess the prognosis, about which we have become less satisfied because an absence of significant symptoms gives no certainty of continuing good health, even for the next few years'.

They discussed the outlook for those in each decade. Very shortly, most did well in the first decade but two died. In the second, many did well but there were four cerebrovascular accidents, none of which proved fatal, but again there were two deaths.

The third and later decades were much less satisfactory. In the third, there were five deaths, including patients with cerebral haemorrhage and aortic rupture. The fourth decade was similar, with two deaths in less than half the number of patients, and there were few patients in the fifth and sixth decades. Incidentally, this series included deaths from all the causes shown in Table 2, but deaths from congestive heart failure formed a much larger proportion.

Campbell and Baylis concluded that, 'though most patients get on well, six who were in good health when first seen died suddenly or relatively so, most often in the third decade. We think therefore that most children 
should have an operation'. These six patients included four in the third and one in each of the first two decades. The two with cerebral haemorrhage and rupture of the aorta seemed as well as usual without exceptionally high blood pressure a few months before they died. The other four died with heart failure, one in the second decade precipitated by bacterial endocarditis and one in the third with severe anaemia where bacterial endocarditis was suspected but could not be proved. The third and fourth deaths, with congestive heart failure in the third decade and left ventricular failure in the second were associated with severe increasing aortic regurgitation. All these patients had seemed to be making satisfactory progress within four and often within two years of their deaths.

Soon after our paper was finished there were two more unexpected deaths: a boy aged 8 with intracranial haemorrhage whose headaches three years before had been attributed to migraine because his blood pressure was only $130 / 80 \mathrm{~mm} . \mathrm{Hg}$; a man aged 22 who died in a crowded hall from a ruptured aorta. I taught that these 8 unexpected deaths among r30 patients within a few years made an operative mortality of about 5 per cent, a small price to pay for the much greater safety after operation.

The position in 1966 In 1956 we had not seen how much precision could have been added to our conclusions about the progress in each decade by using the number of patientyears to calculate mortality rates for each decade. In I 966 two lectures I gave at the Johns Hopkins and at Vanderbilt University, Nashville, on the natural history of malformations of the heart, emphasized our lack of precise knowledge. Trying to gain this, the concept of using patient-years may have been suggested by my life assurance work, comparing expected mortality of diseased and normal subjects, and by my greater familiarity with the Registrar General's Reports from writing about the incidence of coronary heart disease (Campbell, 1963a, b). I first used the method of patient-years for calculating mortality rates in 1966 when working out these rates for persistent ductus arteriosus (Campbell, 1968a). I found then that Wilson and Lubschez (I942) had used the method when contrasting the low mortality of children with persistent ductus in the rest of the first two decades with the heavy mortality in the first two years. Nobody seems to have followed their example. I have subsequently applied the method of patient-years to measure the expectation of life for those with congenital aortic stenosis and pulmonary stenosis (Campbell, 1968b, 1969). Here it is being applied to coarctation of the aorta.

\section{Series where patient-years are available to calculate mortality rates}

I have found only three papers where patientyears can be used to calculate mortality rates: Lewis (1933), Newman (1948), Campbell and Baylis (1956). The others that I hoped would be useful were not: the subjects of Perlman (1944) were all men with coarctation between 18 and 32 years of age, serving in the army. There was no follow-up of any of them so the only conclusion is that middle-aged subjects with coarctation may be apparently fit.

Naturally the paper by Bramwell (1947) was good. His 23 patients, mostly in the second to fourth decades but 3 in the fifth or sixth, were followed for an average of just over 4 years, I03 patient-years in total. During this short time 12 of the 23 died, an over-all mortality rate of II.6 per cent per annum. It was as high as 9.5 per cent even in the second decade and was lower than this only in the fourth decade.

A mortality rate of ro per cent per annum does not mean the whole population dies in Io years because the number of the population at risk decreases each year. It does mean, however, that nearly two-thirds $(65 \%)$ die, while a mortality rate of II.6 means that 7 I per cent will die within ro years. It is clear, therefore, that these patients were too highly selected to give any picture of the natural history of coarctation. Before coarctation began to be widely recognized (about 1947) and sent for consideration of operation, nobody in the Manchester area, and probably at most other places, sent many patients with coarctation to hospital or for a consultation if they were likely to live for many years.

Lewis (1933) followed 8 army pensioners for an average of Io years, most for between 6 and 17 years, and 6 until their deaths. They were between 20 and 49 (average 37.6) years when first found to have high blood pressure, for generally they were not recognized as having coarctation for some years. They were between 31 and 63 (average 47.7) years when they died or were last seen. In 81 patientyears, 6 had died, a mortality rate of 7.4 per cent per annum for those older subjects.

Newman (1948) followed 20 patients whom he diagnosed during their army service (193945) for an average of 4.5 years: 2 had died in 9I patient-years. He saw also three pensioners from 1914-18 with records covering an average of 28 years. Two had died in 85 patient-years and the third was increasingly 
TABLE 3 Mortality rates in coarctation by decades

\begin{tabular}{|c|c|c|c|c|c|}
\hline Decades & Authors & Patients & $\begin{array}{l}\text { Patient- } \\
\text { years }\end{array}$ & Deaths & $\begin{array}{l}\text { Per cent } \\
\text { mortality } \\
\text { per annum }\end{array}$ \\
\hline Ist and 2nd & $\begin{array}{l}\text { (A) Campbell and Baylis } \\
\text { (1956) }\end{array}$ & 78 & 252 & 4 & $\mathrm{I} \cdot 6$ \\
\hline \multirow[t]{2}{*}{3 rd } & $\begin{array}{l}\text { (A) } \\
\text { (B) Lewis (1933) and }\end{array}$ & $\begin{array}{l}37 \\
16 \\
\end{array}$ & $\begin{array}{r}123 \\
94 \\
\end{array}$ & $\begin{array}{l}5 \\
1\end{array}$ & $\begin{array}{l}4 \cdot 0 \\
1 \cdot I \\
\end{array}$ \\
\hline & Newman (1948) & 53 & 217 & 6 & $2 \cdot 8$ \\
\hline \multirow[t]{2}{*}{$4^{\text {th }}$} & $\begin{array}{l}\text { (A) } \\
\text { (B) }\end{array}$ & $\begin{array}{l}17 \\
12 \\
\end{array}$ & $\begin{array}{l}59 \\
64 \\
\end{array}$ & $\begin{array}{l}2 \\
2 \\
\end{array}$ & $\begin{array}{l}3 \cdot 4 \\
3 \cdot 1 \\
\end{array}$ \\
\hline & & 29 & 123 & 4 & $3 \cdot 3$ \\
\hline \multirow[t]{2}{*}{$5^{\text {th }}$} & $\begin{array}{l}\text { (A) } \\
\text { (B) }\end{array}$ & $\begin{array}{l}3 \\
9 \\
\end{array}$ & $\begin{array}{l}18 \\
46 \\
\end{array}$ & $\begin{array}{l}\mathbf{I} \\
3\end{array}$ & $\begin{array}{l}5 \cdot 6 \\
6 \cdot 5 \\
\end{array}$ \\
\hline & & 12 & 64 & 4 & $6 \cdot 3$ \\
\hline \multirow[t]{2}{*}{ 6th and over } & $\begin{array}{l}\text { (A) } \\
\text { (B) }\end{array}$ & $\begin{array}{l}\mathrm{I} \\
8 \\
\end{array}$ & $\begin{array}{l}7 \\
53 \\
\end{array}$ & $\begin{array}{l}0 \\
4\end{array}$ & \\
\hline & & 9 & 60 & 4 & $6 \cdot 7$ \\
\hline All decades & Total & $18 I^{\star}$ & 716 & 22 & $3 \cdot 0$ \\
\hline
\end{tabular}

* There were I6I patients, but several were included in two or more decades.

breathless but still without congestive heart failure.

All these patients of Lewis and Newman were men, unselected except that they had originally been fit enough to serve in the army. It seems best, therefore, to combine them to make the numbers in the fourth to seventh decades somewhat larger. There were Io deaths in 257 patient-years, a mortality rate of 3.9 per cent per annum. The mortality rate increased steadily with age from $I \cdot I$ in the third to 3.1 per cent in the fourth, to 6.5 per cent in the fifth, and to 7.5 per cent per annum in the sixth and seventh decades (Table 3).

The 130 patients of Campbell and Baylis (1956) had been followed for 459 patient-years. It was possible to get these times from my old notes. Though several could be included in the follow-up only for a short time because they had resection soon after their first visit or did not attend hospital again, 8I had been followed for an average period of 5 years, including 2 who had been under observation for 25, years. One of these is still attending the Cardiac Department, Guy's Hospital, 37 years after I first advised her to have no more children because her blood pressure was 220 / I $20 \mathrm{~mm}$. Hg at the age of 25 . Three years later I recognized that she had coarctation of the aorta and was less concerned about her second pregnancy. When 38 , she went through caesarian section successfully. When 46 , she decided it was time to stop going out to work as well as doing all her work at home: her blood pressure was a little higher, 240/120 $\mathrm{mm}$. $\mathrm{Hg}$, than 20 years before but her heart not much larger. When 53, she developed atrial fibrillation and became more breathless, but now (1969), aged 62, she still does her shopping and housework without signs of congestive heart failure. She is mentioned as a matter of interest. Elderly patients who do well have too often been used as an argument against operations. Even she would, I think, have been happier the past Io years could she have had a successful operation when she was young.

Our patients were, of course, mainly hospital out-patients rather than the ideal of unselected schoolchildren. However, the majority had few, if any, symptoms when first seen, and many had been sent for an opinion after coarctation had been found at a routine examination.

Our mortality rates also rose with age, from $\mathrm{I} \cdot 6$ per cent per annum in the first two decades to about 4 per cent in the third and later decades. Of our 459 patient-years, 375 were for the first three decades. This was fortunate because Lewis (1933) and Newman (1948) had no patients in the first two decades and most were in the fourth to sixth decades.

In the three series combined, there were 22 deaths in 716 patient-years. Their distribution by decades is set out in Table 3. The mortality rate was 2.0 per cent per annum for the first decade, excluding the first year of 
TABLE 4 Calculated expected deaths from rooo subjects living at I year with coarctation of aorta

\begin{tabular}{|c|c|c|c|c|c|c|}
\hline & At 10 & At 20 & At 30 & At 40 & At 50 & At 60 \\
\hline \multicolumn{7}{|l|}{ Normal subjects } \\
\hline Deaths among 1000 living at I year & 8 & 15 & 27 & 45 & 87 & I9I \\
\hline \multicolumn{7}{|l|}{ Subjects with coarctation } \\
\hline $\begin{array}{l}\text { Calculated number of deaths among } \\
\text { I000 living at I year }\end{array}$ & 135 & 264 & 445 & 605 & 797 & 898 \\
\hline $\begin{array}{l}\text { Number dead from reported } \\
\text { necropsies (Table I) }\end{array}$ & 47 & 254 & 490 & 692 & 868 & 931 \\
\hline Probable correct estimate in percentages & $9 \pm 4 \cdot 5$ & $26 \pm 0.5$ & $47 \pm 2$ & $65 \pm 4$ & $83 \pm 3.5$ & $91 \cdot 5 \pm I \cdot 5$ \\
\hline
\end{tabular}

life, and I.3 per cent for the second decade. As this difference seems unlikely and one of the four patients died just before reaching the second decade, it seems best to combine these two decades. This gives a mortality rate of I.6 per cent per annum between $I$ and $I 9$ years of age.

For the third decade the results of Lewis and Newman were naturally better than ours, for their patients had been fit enough to serve in the army in this decade. This effect of selection had almost disappeared by the fourth decade, and as expected, the mortality rates were much higher in the fifth and later decades.

The combined rate rose fairly steadily from I. 6 per cent per annum in the first two decades, to 2.8 per cent in the third, 3.3 per cent in the fourth, 6.3 per cent in the fifth, and 6.7 per cent per annum in the sixth and later decades. From these figures shown in the last column of Table 3, the number dying and the number living at the end of each decade can be calculated.

\section{Calculation of mortality and expectation of life from mortality rates}

Table 4 shows the results of these calculations for those who survived the first year of life.

Mortality during the first year The very high mortality of most cardiac malformations during the first year of life is widely recognized. There are three series where all infants born with cardiac malformations in certain areas were carefully followed: (I) MacMahon, McKeown, and Record (1953); (2) Carlgren (1959); and (3) J. Hay and R. W. Smithells (1965, personal communication on the number of children with cardiac malformations born in Liverpool 1960-64). All these give a very high mortality for subjects with coarctation of the aorta during the first year of life, from 45 to 84 per cent. It seems unlikely that it is much less than 60 per cent (Campbell, r968c), and the continuing work of Hay and Smithells with the Liverpool Malformations Registry should soon give a more precise answer (Hay, 1966).

Calculation of subsequent deaths by decades This paper is concerned with the mortality and expectation of life for those who have survived these serious hazards of the first year, and the results are shown in Table 4. The first line shows the expected deaths in 1000 normal people surviving their first year. The population is adjusted to include two normal men for each normal woman to balance the sex incidence of coarctation. It is taken from the Life Table No. I I of the Registrar General (1957).

The second line shows the calculated deaths among $I, 000$ subjects with coarctation of the aorta who survived their first year. The figures were calculated for each year, though only those for the end of each decade are shown. The deaths in the first two decades were 18 times as many as in a normal population and still 13 times as many in the fourth, though by the sixth decade when more normal people die only 5 times as many.

Over one-quarter had died by 20 , half by 33, and over three-quarters by 50 years. These figures from my calculations may remind the reader of the similar ages found from the reported necropsies (Table I) which are repeated in the third line of Table 4. The close agreement of these two completely independent methods is most satisfactory.

These two methods did not agree nearly as well for persistent ductus, and there the data for my calculations were more extensive and seemed more reliable. For coarctation the number of patient-years for calculation were relatively small and there is probably some luck in their agreeing so closely. Almost certainly the true values lie between or near to the limits shown in the bottom line of Table 4 


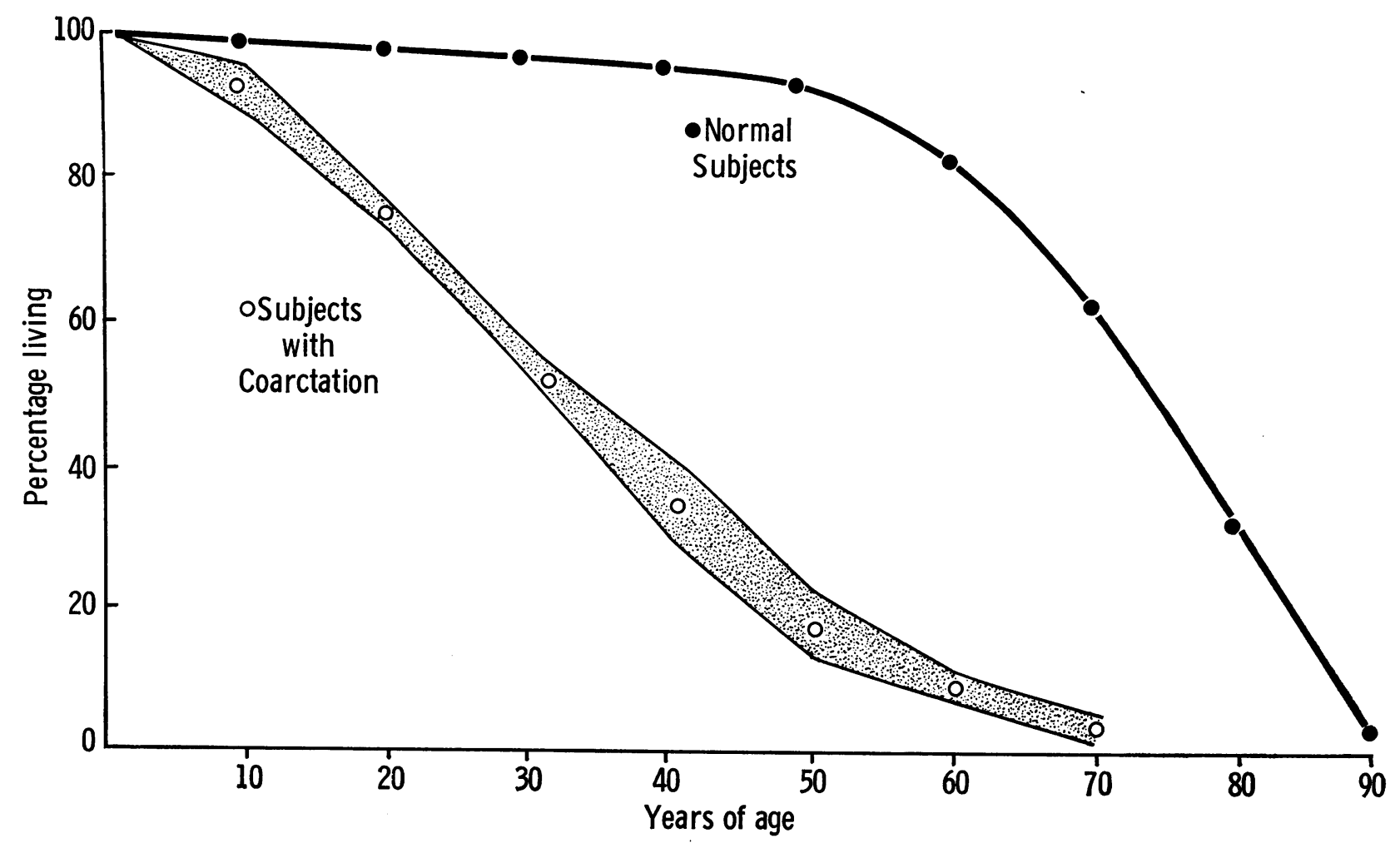

FIG. 2 The number of subjects still living among those surviving the first year of life. For those with coarctation of the aorta on the left, and for normal subjects on the right. The broader band for coarctation of the aorta shows the relatively close agreement between the ages from reported necropsies and from my calculations from deaths of patients under observation.

and in the relatively narrow band in Fig. 2. Only in the first decade does the difference seem important. A small part of it is explained by the reported necropsies excluding children who died during their second year. Probably in the main it is because there were too many deaths of children in my hospital series and too few recognized and included among the reported necropsies.

Fig. 2 expresses the same results in a different way. It compares the number of subjects with coarctation still alive at the end of each decade with the numbers of normal subjects surviving.

The median age of death for subjects with coarctation is 31 years, instead of 72.5 years as normally. The deaths were widely spread over the second to fifth decades rather than closely clustered round the mode. This is not, therefore, very significant, and is in the third decade for the reported necropsies and shared between the third and fifth decades for the calculated deaths, instead of the eighth decade as normally (Fig. I).

The arithmetical mean of the ages of death is 34 years for the reported and calculated deaths but with very wide variations, standard deviations of \pm 16 and \pm 19 years. For normal subjects it is $71 \pm 15.5$ years, so the wide variation is not surprising.

Incidence of bacterial endocarditis in coarctation and other cardiac malformations

In my I30 patients with coarctation, 6 acquired bacterial endocarditis while they were under observation, excluding one who was sent because he had developed it. This in 459 patient-years means an incidence of $\mathrm{I} \cdot 3$ per cent per annum, a higher incidence than in most other cardiac malformations (Table 5). I felt this could be explained by the liability of bicuspid aortic valves to bacterial endocarditis, but the true incidence may not be as high as this.

The second column in Table 5 shows the incidence as measured from reported necropsies. Eighteen per cent of 304 patients died with bacterial endocarditis and they come from a period when every infection was fatal, 
so all must be included. But the mean duration of life of these patients was 29 years so the incidence was only 0.6 per cent per annum. I see no reason for thinking one method is more accurate than the other: the difference is even larger, but the other way round, for persistent ductus where the necropsies were also before bacterial endocarditis could be cured (Campbell, 1968a).

The lower incidence in the necropsy series for pulmonary stenosis could be explained, as several patients who were cured of their endocarditis would not appear in the figures (Campbell, 1969). The true figure is, therefore, nearer the 0.9 per cent of the first column. The lack of agreement shows that the numbers are not large enough to give accurate results. It is, therefore, impossible to say which malformation has the highest incidence of bacterial endocarditis and only possible to say that the incidence in all these four malformations is about $0.9 \pm 0.4$ per cent per annum. This, of course, is quite high, about 9 per cent being infected each decade.

\section{References}

Abbott, Maud E. (1928). Statistical study and historical retrospect of 200 recorded cases, with autopsy, of stenosis or obliteration of the descending arch. American Heart fournal, 3, 392 and 574.

- (1936). Atlas of Congenital Cardiac Disease. American Heart Association, New York.

Bramwell, C. (1947). Coarctation of the aorta: II. clinical features. British Heart fournal, 9, 100.

Bullock, L. T., Jones, J. C., and Dolley, F. S. (1939). The diagnosis and the effects of ligation of the patent ductus arteriosus. Fournal of Pediatrics, 15, 786.

Campbell, M. (1963a). Death rate from diseases of the heart: 1876-1959. British Medical fournal, 2, 528.

- (1963b). The main cause of increased death rate from diseases of the heart: 1920 to 1959. British Medical Fournal, 2, 712.

- (1968a). Natural history of persistent ductus arteriosus. British Heart fournal, 30, 4 .

- (1968b). The natural history of congenital aortic stenosis. British Heart Fournal, 30, 514.

- (1968c). The incidence and later distribution of malformations of the heart. In Paediatric Cardiology, p. 71. Ed. by Hamish Watson. Lloyd-Luke (Medical Books), London.

- (1969). Natural history of congenital pulmonary stenosis. Festschrift for Professor Condorelli.

-, and Baylis, J. H. (1956). The course and prognosis of coarctation of the aorta. British Heart fournal, 18, 475.
TABLE 5 Incidence of bacterial endocarditis

\begin{tabular}{|c|c|c|}
\hline \multirow[b]{2}{*}{ Condition } & \multicolumn{2}{|c|}{ Per cent incidence per annum } \\
\hline & $\begin{array}{l}\text { From series } \\
\text { where patient- } \\
\text { years were } \\
\text { available }\end{array}$ & From reported necropsies \\
\hline Coarctation of aorta & $\mathbf{I} \cdot 3$ & $\begin{array}{l}0.6 \%, \text { in } 18 \text { of all reported } \\
\text { necropsies }\end{array}$ \\
\hline Pulmonary stenosis & 0.9 & $\begin{array}{l}0.4 \% \text {, in } 7 \% \text { of all necropsies } \\
\text { (Fontana and Edwards, 1962) }\end{array}$ \\
\hline Congenital aortic stenosis & 0.9 & Not available \\
\hline Persistent ductus arteriosus & 0.5 & $\begin{array}{l}\text { I. } 5 \% \text {, in } 45 \% \text { of all necropsies } \\
\text { (Bullock et al., I } 939 \text {; Shapiro } \\
\text { and Keys, I } 943 \text { ) }\end{array}$ \\
\hline
\end{tabular}

- and Suzman, S. (1947). Coarctation of the aorta. British Heart fournal, 9, 185.

Carlgren, L.-E. (1959). The incidence of congenital heart disease in children born in Gothenberg $1941-$ 1950. British Heart fournal, $21,40$.

Fawcett, J. (I905). Coarctation of the aorta. Guy's Hospital Reports, 59, I.

Fontana, R. S., and Edwards, J. E. (1962). Congenital Cardiac Disease. W. B. Saunders, Philadelphia.

Hay, J. D. (1966). Population and clinic studies of congenital heart disease in Liverpool. British Medical fournal, 2, 66I.

Lewis, T. (1933). Material relating to coarctation of the aorta of the adult type. Heart, 16, 205.

MacMahon, B., McKeown, T., and Record, R. G. (1953). The incidence and life expectation of children with congenital heart disease. British Heart fournal, 15, 121 .

Newman, M. (1948). Coarctation of the aorta: review of twenty-three service cases. British Heart fournal, 10, 150.

Perlman, L. (1944). Coarctation of the aorta: clinical and roentenologic analysis of 13 cases. American Heart fournal, 28, 24.

Registrar General (1957). Decennial Supplement, England and Wales, 195I. Life Tables, pp. 31-34.

Reifenstein, G. H., Levine, S. A., and Gross, R. E. (1947). Coarctation of the aorta: a review of 104 autopsied cases of the 'adult type'. American Heart fournal, 33, 146 .

Shapiro, M. J., and Keys, A. (1943). The prognosis of untreated patent ductus arteriosus and the results of surgical intervention. American fournal of the Medical Sciences, 206, I74.

Wilson, M. G., and Lubschez, R. (1942). Prognosis for children with congenital anomalies of the heart and central vessels. Life expectancy in patent ductus arteriosus. Fournal of Pediatrics, 21, 23. 